\title{
Incorporating Task Based Language Learning Approach into a Kurdish Young EFL Learners' Classroom through Storytelling Technique in a Basic School in Kurdistan Region
}

\author{
Atta Hamamorad \\ College of Basic Education \\ Halabja University
}

\begin{abstract}
Effective teaching of English language to EFL learners has always been an important issue. There has been continuous efforts to find and adapt teaching methods and styles which suit learners' context, needs, and interest. This paper tries to devise a lesson for Kurdish young learners of grade six in a primary school in Kurdistan Region through integrating Task Based Learning aspects with the characteristics of Storytelling Method. Efficacious language learning approaches prioritise enhancing learners' communicative performance over teaching complex grammatical structures in the early stage of learning a foreign language. Similarly, Task Based Language Learning approach aims to develop learners' communicative competence via engaging them in authentic language activities and tasks. Storytelling technique on the other hand, can create an energetic, friendly ambiance in which learners are enthusiastically immersed in the lesson. They speak more confidently and are less afraid of making mistakes. The technique adapted, is new and novel in Kurdistan region's basic schools however, it falls within the scope of Communicative Teaching Approach which has recently become the popular approach for teaching English Language in basic schools of the region in the last few years.
\end{abstract}

Keywords: young learners, task based language learning, storytelling, task cycle

\section{Introduction}

Teaching English to Young Learners (TEYL) is a field of education which has witnessed a rapid growth around the world. English language teaching has widely been adopted in the primary levels worldwide. This trend has appeared in a time when ESL/EFL field is experiencing a remarkable shift from structural, teacher-centered approaches to communicative, task-based and learner-centered approaches. These new approaches recognize that learner engagement and affective aspect are of great significant in acquisition and learning of a foreign language. They offer an interactive, reduced-anxiety, and amusing atmosphere in which learners generally and young learners in particular, can effectively learn the target language.

\section{Rationale}

Task based language learning (TBLL) also known as Task Based Language Teaching (TBLT) or Task Based Instruction (TBI) concentrates on using authentic language and promoting learners' engagement and communication in the target language by providing meaningful tasks. It aims at enabling learners to acquire new linguistic knowledge as well as helping them proceduralise their existing knowledge. It has its roots in CLT approach. In TBLL, specific needs of learners and the suitable ways of learning the target language are prioritized whereas morphological, phonological and lexical elements of language like phonology, grammar, discourse and vocabulary are considered secondarily in curriculum design (Nunan 1991). According to Larsen-Freeman and Anderson (2011), TBLL aims to facilitate learning by involving learners in a variety of activities and tasks that carry a clear result.They set three stages for TBLL which are:

Teacher introduces the learners to the language that they need for accomplishing the activity or the task. The task should be purposeful and related to every day life experience so that the learners can make better sense of it.

Teacher encourages students to actively participate and engage in the task. The teacher has a monitoring role and intervenes whenever and wherever is needed. The clarity of task objective is crucial as it makes the teacher and learners be aware of when the objective of the task is achieved and can move to another task or activity. 
In the last stage, the teacher addresses and identifies the problems which may arise in learners' learning. He/she also reinforces learners' learning by providing suitable feedback.

In TBLL, learners are regularly exposed to the target language through communicative and social situations which are created in the classroom. Therefore, learners are provided with sufficient comprehensible input. Learners are also given chances to participate in the communicative situations in the classroom in order to utilise target language and produce a comprehensive output.

TBLL has a close connection with young learners' characteristics. Some general characteristics of young learners and TBLL's connection to them can be highlighted as follow:

Learners' needs: young learners as language learners are always looking for meaning (Cameron 2003). They are actively engaged in formulating rules that lead them to understanding the world (Wells 1987). Meanwhile methodological characteristics of TBLL emphasize that language learning activities should directly reflect what learners actually and potentially need to do with the target language (Nunan 1991).

Focus on form: young learners are in the stage of developing first and second language and they are getting familiarized with the written form of the words (Cameron 2003). Regarding this fact, in TBLL language features are taught according to learning needs and capacity. Therefore, complex grammatical, phonological and discourse features are considered secondary and taught in later stages. Young learners in this stage do not need to explicitly be taught these elements because they are developing their skills to understand the concept of the language rule (Nunan 1991).

Communicating in the target language: young learners are less constrained and limited than adult learners to talk in the target language and if the topic of the task interests them, they will initiate communication nevertheless most of them lack self-consciences when they speak in a new language (Mcllvain 2004). This aspect in TBLL has been taken into consideration and ccommunicative tasks designed in TBLL, intend to promote communicative competence of the young learners (Ellis 2003).

Curriculum flexibility: young learners are naturally curious and like to explore new things. They tend to ask questions and experiment with the language (Tizard \& Hughes 1984). This aspect has not been neglected as in TBLL young learners influence curriculum design. They can change the course of the activity or the task by going beyond the expected objective due to their natural curiosity toward new experiences. This approaches provides young learners with space, to the extent that teacher finds it appropriate and useful, to conduct the learning process. Therefore, teacher can control the instruction of the lesson in favor of a learner-centered teaching process (Willis 1996).

Correction of form: young learners have specific literacy demands and capacities. They might not be ready to grasp certain linguistic complexities and structures either in their first or the target language (Mcllvain 2004). Considering this, TBLL stresses on acquiring the form which essentially fosters acquisition of formal linguistic elements but suggests that this should happen in natural interventions during accomplishing the tasks (Harley\& Swain 1984).

Story-telling on the other hand, is an art, the act of narration by which language and gestures are ingeniously manipulated to generate scenes in a sequence (Champion 2003) ; however, this art may exceed merely telling a story and incorporate other elements like pictures, costumes, ornaments, real objects, musical instruments, school books, and so on. Young learners love stories and are always avid to listen to them. They know how a story works. They enjoy by listening to stories narrated by their parents, grandparents or elder siblings to them in bed before asleep. They are, to some extent, familiar with stories even before attending the school. Storytelling is a unique method of communication and learners express their thoughts and ideas in their own unique ways. Haven (2000 p.57) considers storytelling to be powerful, impressive and motivating and states that "Factual and conceptual information is learned faster and better, and will be remembered longer, recalled more readily, applied more accurately when that information is delivered as a well-told story".

Stories also give the teacher more freedom and a better opportunity to plan and organise the lesson in a way that he/she likes. Furthermore, they suit learners' interests. Stories help young learners practice all things that they have learned in an integrated lesson environment.

Ellis and Brewster (1991) recommend teachers to integrate stories into their teaching. They also put forward some benefits of adapting stories for teaching/learning such as: 
- Story is fun and motivating and generates a profound desire and interest for learners to pursue learning.

- When learners listen to a story, they share a social experience. Story instigates their shared response of sadness, anticipation, laughter and excitement.

- Story exercises learners' imagination; learners are personally engaged in the story while they are identifying with its characters and trying to analyse the narrative and illustrations.

- Stories link imagination and fantasy with learners' real life and world. They help learners make sense of and understand their everyday life.

- While learners are listening to stories, the teacher can expose them to language by introducing or revising sentence structures or new vocabulary.

- Stories introduce universal truths and moral lessons which appeal to one generation after another.

Furthermore, storytelling is an influential way for the early foreign language class because its purpose is genuinely communicative and appeals to affective side of the learners. It also gives them a chance to experience listening with a reduced anxiety (Curtain \& Dahlberg 2004).

By carefully concentrating on TBLL approach and storytelling, it will be obvious that they share some similar characteristics. In Schnank (1998) s' view, elements of TBLL approach are apparent in storytelling method through two independent mechanisms which are storyteller and task environment. She poses that "the task environment provides learners with engaging, motivating activities, the teacher monitors the task environment, looking for opportunities to present tasks that will help learners to learn"(p. 105). Storytelling and TBLL help learners learn from their interactions by providing them with and exposing them to various situations, tasks and activities.

\section{Teaching Context and learners' background}

In Kurdistan region, English language is taught in primary schools in a drip feed situation. English language is a major subject which is taught two hours per week along with other subjects. The current curriculum for teaching English in primary schools in Kurdistan is based on CLT approach which encompasses TBLL method.

The focus of the proposed lesson is young learners of age 11 - 12 years in grade 6 in a Kurdish primary school. These young learners have been taught basics of English language like vocabulary items, writing and reading words and sentences, composing paragraph as well as certain routines and patterns from grade three. They have experienced engaging in communicative tasks and situations through 'dialogues, Look and Say, Listen and Say' activities and so on. However, they are not still competent communicators and tend to use first language in a number of situations. They are well-established at school and comfortable with school routines. They have a growing understanding of the world around them and are interested to involve in real life issues. They have a longer attention span compared to pupils in lower grades as their intellectuality is more developed so that they can engage in a task or an activity which lasts for ten or fifteen minutes without getting bored. They also have a clearer understanding, compared to younger learners, of discourse and more importantly, of why they are learning a new language (Pinter 2005).

\section{Task Cycle}

\subsection{Aim}

The aim of using storytelling for teaching young learners in this proposed lesson is to promote their oracy skills as well as focusing on some certain vocabulary items derived from the story.

Although speaking and listening are different skills but they are closely intertwined and they are fundamental elements for a successful, understandable communication. According to Cameron (2001 p.40) "Listening and speaking are both active uses of language, however they are different in the mental activity demands they make on learners with regard to finding and sharing meaning. Listening can primarily be regarded as the active use of language to access other people's meanings, whereas speaking is the active use of language to express meaning so that other people can make sense of them". On the other hand, teaching learners the vocabulary items which are frequently and commonly used, is a good means to enrich their target language repertoire. Story presents vocabulary items in a clear and vivid context and elaborations can help express meaning (Ellis \& Brewster 1991). 


\subsection{Resources}

The required materials for teaching this lesson are whiteboard, pictures which are related to the target story, worksheets, and storyteller traditional costume.

\subsection{Phases of implementing storytelling process}

\subsubsection{Pre-task phase}

According to Willis (1996 p.43) pre-task activities that present the language focus topic "should actively involve all learners, giving them relevant exposure, and [...] create interest in doing a task on this topic". Therefore, the pre-task stage, teacher should ensure that pupils (young learners) have a clear understanding of the task requirement, its goal and outcome. In addition to explaining the task, he can demonstrate the task with a good, competent pupil or show the class what previous pupils have achieved.

Skehan (1998) similarly states that since learners' attentional capacity is limited. The teacher in pre-task phase can emphasize on the general cognitive demands of the task as well as on linguistic factors.

\subsubsection{During-task phase}

For this stage the teacher according to Brewster, Ellis and Girard (2004) can perform the following techniques:

If possible, gathering all the pupils around in a form of a circle or semicircle so that every pupil can see and hear the teacher and illustration clearly.

Reading the story slowly and clearly so as to give the pupils time to link what they hear to the pictures they see. This also provides pupils with an opportunity to ask questions, think and make comments.

Teacher can encourage pupils to participate in the storytelling by repeating vocabulary items and key phrases and expressions.

Teacher can vary his/her tone and volume of sound to create suspense or an element of surprise by raising the voice (Skehan \& Foster 1999).

Teacher can also ask questions to engage students and keep their attention.

$\mathrm{He} / \mathrm{She}$ can also repeat, reformulate and expand the story elements and ideas to make sure it is comprehensible for the pupils.

\subsubsection{Post-task phase}

In this stage, pupils are provided with a chance to repeat the performance of the task. Teacher encourages them to reflect on how the task was performed. He can also focus on forms particularly those which were problematic during the task performance. Research has shown that there is a case for asking pupils to repeat a task (Bygate 2001) because when they repeat a task, their production improves in a number of ways such as increase of complexity, clearer expression of prepositions, and pupils become more fluent. Encouraging pupils to reflect on their performance may contribute to the development of meta-cognitive strategies of planning, monitoring and evaluating which are considered important for language learning (O'Malley\& Chamot 1990). Ellis (2003) sees the primary goal of the task to be developing fluency and promoting communicative strategies while she considers focus on form as secondary goal.

\section{Procedure}

Estimated Lesson time: 50 mints.

Number of pupils: 25

\section{Objectives}

Promoting listening\& speaking, and teaching new vocabulary. 
The teacher starts the lesson by telling the young learners (pupils) that in this lesson they are going to listen to a story. Then s/he directs some brainstorming questions in the first language about the story (See appendix. A). Later, he/she shows some pictures related to the story and explains it briefly in the first language (See appendix. B). In the next step, he/she introduces the new vocabulary items which are derived from the story, writes them on the whiteboard along with their meaning in the first language. After that, the teacher reads the vocabulary items once and asks the whole class to repeat after him/her (See appendix C). S/He then asks pupils to listen to the story attentively as he begins to narrate in English language. S/He starts reading slowly and clearly so that the learners can follow and relate what they hear to what they see in the pictures. S/He can also use repetition to emphasize on a particular word or sentence during storytelling process. S/He uses gestures and asks questions in order to keep the attention of pupils and whenever s/he found that pupils have problem in understanding a particular word or sentence, s/he can use the first language for scaffolding as necessary. Another element worth focusing in this process is prediction. The teacher tells the story to the climax and then he pauses and asks pupils to predict what will happen or what would they do if they were in that situation. Once they have verbalized their own ending for the story, the teacher continues and finishes the story (See appendix D).

In the final step of the storytelling, the teacher reads the story once more in the target language without using the first language while pupils are listening carefully. Then he extracts the moral lesson of the story, writes it on the board and explains it to the learners using first and second language.

For the post-task storytelling process, teacher can make use of the techniques stated below:

Preparing some comprehension questions for learners to answer orally (See appendix. F).

Group retelling to encourage learners to retell the story. $\mathrm{S} / \mathrm{He}$ retells the story with gaps and pauses and asks learners to fill those gaps (See appendix. G)

Encouraging learners to create their own ending for the story by writing a paragraph. The teacher can assign this activity as homework so that pupils are given enough time to re-read the story at home and master the vocabulary items completely so as to use them in their writing.

Story boarding to help learners understand the plot of the story. Learners can draw pictures to show the plot of the story sequentially. The pictures can be accompanied by dialog bubbles or text.

The last useful sort of activity is project. Teacher can divide the learners into small groups and encourages them to work together and do a performance of the story or create a wall display for the story. This activity can be accomplished later, due to time constrain, as homework. Also Total Physical Response (TPR) technique can be used to keep pupils lively and focused. (See appendix. E).

\section{Possible Problems}

There are several anticipated problems which may occur while conducting storytelling lesson. The first problem is the large number of learners in the class. In primary schools in Kurdistan region, each classroom approximately accommodates 25 learners. When teacher tells a story, some of the learners may not be able to see and hear him clearly. To solve this, the teacher can arrange the desks in a circle or semicircle form so that all learners can vividly see and listen to him. Another problem would be noise and fear of losing control of the class (Appel 1995) which this may impede or disturb the teaching process. This is a common problem in large classes. Learners speak to each other during narrating the story, or during performing group tasks. To overcome this issue, teacher can walk around and monitor to keep order and make sure that learners are busy doing their task. The third problem might be that some learners (weak learners) may not understand the story or task instructions clearly. To cope with this, teacher can use first language to explain the instructions and consecutively repeat the instructions in the target language. He can also form groups which include weak and more competent learners together so that competent learners can cooperate and help weak learners in doing the task.

Learners' individual differences and diversity is another problem which may arise during storytelling lesson. Learners have different characteristics and abilities. They furthermore, differ in comprehending, thinking, or processing information (Jensen 1998). Some learn quickly whereas some are slow learners. Some are auditory, some others are visual or kinaesthetic. For this, teacher can provide variety of activities and aids like tape, personal narrating, pictures or videos as well as extra activities which are a little more challenging. Those learners who finish the task quicker in a correct way, are given these extra activities to accomplish. 
Linguistic and pronunciation problems are another aspect that may appear during doing communicative tasks or answering questions. Teacher can let the learner continue speaking as long as he/she can convey his/her message without being interrupted. Teacher can also correct and provide scaffolding whenever the learner is stuck and meanwhile, he should avoid interrupting and correcting the learner for every error or mistake as this may lead him/her to losing or forgetting the point or being disappointed and frustrated.

Young learners are active and lively people and if they are clung to one sort of activity for a long time they may lose focus, get bored and play around or make noise. To keep them focused and attentive, teacher can adopt some total physical response (TPR) techniques.

Use of the first language in the classroom is another issue. Teachers vary in the amount of the first language they use however, it should not be over relied on (Turnbull 2001). It is most commonly used to manage classroom behaviour and activity as well as maintaining order and formality in the class. In this regard, the teacher should use the target language equivalent of the instruction or command and repeat it (uses target language first then uses its equivalent in the first language or vice versa) so that learners will understand clearly and can simultaneously learn new vocabulary items. Moreover, sometimes learners during the lesson or performing the tasks are unable to utter the suitable word or sentence to express their meaning as a result, they resort to the first language. In this case the teacher can scaffold them by telling $\mathrm{him} / \mathrm{her}$ the appropriate word or expression in the target language and asking them to repeat loudly. Thus, the learner and the entire class can hear and learn the word and expression as well as its meaning and pronunciation.

Shortage of time is another serious predicted problem. The teacher should carefully consider learners' language level and the level of difficulty of the tasks in order to manage his/her class time. He should evaluate the task and anticipate the required time for each task before starting the lesson.

\section{Conclusion}

Speaking and listening are two skills which are highly interrelated. Listening is the receptive activity which leads to speaking. When teacher speaks and explains, pupils listen and when a pupil speaks, others listen. This is in accordance with the TBLL's principles which importantly focus on boosting communication and interaction among learners. Storytelling can also enhance both skills in the classroom as it attracts the attention and the interest of pupils and involves them in communicative, interactive tasks and activities.

TBLL approach suits young learners. According to second language learning acquisition theory (Krashen 1981; Long 1991; Ellis 2003) the ultimate goal of teaching a foreign language to young learners is to enhance their communicative competence and avoid teaching complex grammatical structures in the early stages of learning or acquiring a foreign language. Likewise, TBLL's primary aim is to develop communicative competence of learners through engaging them in authentic language tasks and materials.

Storytelling can create a friendly, lively atmosphere in which pupils are actively engaged in the lesson and they feel more confident. They try to participate and use the target language.They are less afraid of making mistakes.

When choosing a story, it is necessary that teachers regard pupils' language level and their interests. The story should be motivating and interesting for pupils in order for the story and the related tasks to promote pupils language skills, creativity and bring their inner imaginative capabilities to the forefront.

However storytelling is not a common method for teaching English language in Kurdistan primary schools but I think it is a very useful method to make use of as it is in line with our community traditions (narrating stories and anecdotes that carry moral lessons to amuse children and teach them different values and manners). Also translating our stories into English and teaching them in the classroom is an influential way to re-introduce our culture and traditions to our Kurdish pupils.

\section{References}

[1] Appel, J. (1995). Diary of a Language Teacher. Oxford: Heinemann.

[2] Brewster, J., Ellis, G., \& Girard, D. (2004). The primary English teacher's guide. London: Penguin.

[3] Bygate, M. (2001).Effects of task repetition and control of oral language. In M. Bygate, M. Swain Eds. Pp.23-38

[4] Cameron, L. (2001).Teaching Languages to Young Learners. Cambridge: Cambridge university press. 
[5] Cameron, L. (2003) Challenges for ELT from the expansion in Teaching Children.ELT Journal, 57(2), 105-112

[6] Champion, T. B., Katz, L., Muldrow, R., \& Dail, R. (1999). Storytelling and story making in an urban preschool classroom: Building bridges from home to school culture. Topics in Language Disorders, 19(3), 52-67.

[7] Curtain, H. \& Dahlberg, C.A. (2004). Languages and children: making the match. Boston: Pearson

[8] Ellis, G. \& Brewster, J. (1991).Handbook for primary teachers. Penguin Books

[9] Ellis, R. (2003). Task-based Language Learning and Teaching. Oxford: Clarendon press.

[10] Harley, B. \& Swain, M. (1984). The Interlanguage of immersion students and its implications for Second Language Teaching. Edinburgh: Edinburgh university press.

[11] Haven, K. F. (2000). Super simple storytelling: a can-do guide for every

[12] classroom, every day. Englewood, Colo.: Teacher Ideas Press.

[13] Jensen, E. (1998). Introduction to Brain-Compatible Learning. San Diego, CA: The Brain Store, Inc

[14] Krashen, S. (1981).Second language acquisition and second language learning. Oxford: Pergamon Press.

[15] Larsen-Freeman, D., \& Anderson, M. (2011). Techniques and Principles in Language Teaching (3rd Ed.). New Yok, NY: Oxford University Press.

[16] Mcllvain, A. (2004). Teaching English to very young learners. Selected Papers from the Amazing Young Minds. Cambridge: Cambridge university press.

[17] Nunan, D. (1991). Communicative tasks and the language curriculum. TESOL QUARTERLY, 25(2):279-295

[18] O'Malley, J. M., \& Chamot A. U., (1990).Learning Strategies in Second Language Acquisition. Cambridge: Cambridge University Press

[19] Pinter, A. (2005). Task reception with 10-year old children. Teachers' Exploring Tasks in English Language Teaching. Eds. Willis, J. \& Edwards, C. Basingstoke: Palgrave MacMillan.

[20] Schnank, R., C. (1998). Inside Multi-Media Cased Based Instruction, (Ed.). NJ, Mahwah: Lawrence Erlbaum Associates, Inc.

[21] Skehan, p. (1988). A Cognitive Approach to Language Learning. Oxford: Oxford university press.

[22] Skehan, P. \& Foster, P. (1999). The influence of task structure and processing conditions on narrative retellings. Language Learning, 49 (1), 93-120

[23] Tizard, B. \& Hughes, M. (1984). Young Children Learning. Cambridge, Mass: Harvard university press

[24] Turnbull, M. (2001). There is a role for the L1 in second and foreign language teaching, but? The Canadian Modern Language Review, 57(4), pp. 531-535.

[25] Wells, G. (1987). The Meaning Makers: Children Learning Language and Using Language to Learn. London: Hodder and Stoughton educational.

[26] Willis, J. (1996). A framework for task-based learning. Harlow: Longman 
